\title{
Effect of a high-palmitic acid fat supplement on milk production in Icelandic dairy cows fed grass silage-based diet
}

\author{
JóHANNES SVEINBJörnSSON ANd HrafNHILdUR BaLdURSDótTIR \\ Agricultural University of Iceland, Faculty of Agricultural \& Environmental Sciences, \\ Hvanneyri, IS-311 Borgarnes, Iceland. \\ E-mail:jois@lbhi.is; litlaarmot@gmail.com
}

\begin{abstract}
Thirty-seven dairy cows of the Icelandic breed were used in a change-over design experiment. The aim was to analyse the effects of moderate addition of high-palmitic acid (C16:0) fat supplement to a grass silage-based diet. There were three experimental treatments: a treatment with the fat supplement as powder (FAPOW); a treatment with the fat supplement in pelleted concentrate (FAPEL); and a control treatment (CONTROL). Milk protein content was significantly lower, and there was a tendency $(\mathrm{p}<0.10)$ toward a higher milk fat content in the fat treatments. This resulted in significantly higher milk fat:protein ratio in the fat treatments compared to the control (FAPOW 1.21 and FAPEL 1.20; CONTROL 1.15). A significant reduction in the ratio of casein in milk protein due to fat addition explains the reduction in milk protein. The concentration of free fatty acids in milk was higher in the fat treatments, especially FAPEL. The ratio of C16:0 in total fatty acids was increased by the fat treatments.
\end{abstract}

Keywords: fat supplement, milk fat, milk protein, fatty acids, dairy cows.

\section{YFIRLIT}

Áhrif fituiblöndunar í fóður mjólkurkúa á nyt og efnainnihald mjólkur

Tilraunin sem hér er sagt frá var skipulögð pannig að 37 íslenskar mjólkurkýr voru látnar prófa prjár fóðurmeðferðir, í mismunandi röð. Markmiðið var að greina áhrif hóflegrar fituviðbótar, aðallega á formi pálmasýru (C16:0), í fóður mjólkurkúa par sem vothey verkað úr grasi er undirstaðan. Fóðurmeðferðirnar prjár voru: fituviðbót á formi purrfitu (FAPOW); fituinnblöndun í kjarnfóðurblöndu (FAPEL); og viðmiðunarfóðrun án fituviðbótar (CONTROL). Hlutfall próteins í mjólk var lægra og tilhneiging til hærra mjólkurfituhlutfalls pegar fitu var bætt í fóðrið. Petta leiddi til marktækt hærra fitu: prótein hlutfalls í mjólkinni í fóðurmeðferðum með viðbótarfitu í samanburði við viðmið (FAPOW 1.21 og FAPEL 1.20, samanborið við CONTROL 1.15). Lækkun á hlutfalli kaseins í mjólkurpróteini vegna fituviðbótar í fóðri skýrir áðurnefnda lækkun á heildarpróteini í mjólk. Styrkur frjálsra fitusýra í mjólk var hærri pegar fitu var bætt í fóður, sérstaklega pegar pað var gert í gegnum kjarnfóðurblöndu (FAPEL). Hlutfall pálmasýru af fitusýrum í mjólk var hærra pegar fitu var bætt í fóðrið.

\section{INTRODUCTION}

The dairy market in Iceland has undergone substantial changes in recent decades. Since 1994, the market for milk protein has increased proportionally with population growth. However, the demand for milk fat decreased from 1994 to 2003 but has since then been increasing at a rate double the increase in milk protein demand (Auðhumla 2019). To respond to proportional changes in fat $v s$. protein demand, dairy farmers at any time require knowledge 
about available methods to alter the fat:protein ratio in the milk produced.

The three main components of milk dry matter are lactose, protein and fat. The amount of lactose produced largely controls the volume of milk, as it is the osmotic pressure exerted primarily by lactose that draws water from blood into the alveolar compartment (Guinard-Flament et al. 2006). Therefore, the lactose concentration in milk is not sensitive to dietary changes. Milk protein concentration is positively influenced by increased the dietary energy level, except in the form of dietary fat; its addition often reduces the milk protein concentration. The effects of the amount or source of dietary protein on milk protein concentration are modest (Jenkins and McGuire 2006).

Fat is the milk component that is by far the most sensitive to diet composition (Jenkins and McGuire 2006). Therefore, if the market situation demands alterations in the milk fat:protein ratio, the most auspicious way to address that situation would be to try to influence the milk fat concentration by changing the composition of the dairy cow's diet.

A bulk of studies on dietary influences on cow milk fat deal with "milk fat depression" (MFD), a problem that occurs when feeding a particular diet that markedly reduces the fat content and alters the fatty acid (FA) composition of milk (Bauman and Griinari 2003). The "biohydrogenation theory" proposed by Bauman and Griinari (2001) is based on the concept that under certain dietary conditions the pathways of biohydrogenation of unsaturated FA by rumen bacteria are altered to produce unique FA intermediates, some of which are potent inhibitors of milk fat synthesis. A typical condition for this to occur would be a diet with a high content of polyunsaturated fatty acids (PUFA's) and a low content of effective fibre (Bauman and Griinari 2003). The effectiveness of dietary fibre is defined by its ability to buffer rumen $\mathrm{pH}$, maintain normal chewing time and rumination, stratification of rumen contents, and other conditions necessary for maintaining normal rumen function (Beauchemin 2018). Fibre in grass silages is more effective than fibre in maize silages in maintaining rumen function that supports normal milk fat content (Bauman and Griinari 2003). Many of the studies of dietary effects upon milk fat content are from the parts of the world where maize rather than grass silage is the main forage source for lactating dairy cows. Recent studies at Michigan State University have underlined the conclusion that adding dietary fat in the form of palmitic acid (C16:0) is an effective way of raising the milk fat content in diets where maize silage was the major forage component (Lock et al. 2013, Piantoni et al. 2013, Rico et al. 2014b).

The current situation in the Icelandic dairy industry requires dietary changes that increase the fat:protein ratio in the milk. The aim of the present study was to investigate the effects of adding palmitic acid to a typical grass silagebased diet. Two different approaches in adding the fat were tried.

\section{MATERIALS AND METHODS}

Animals and experimental design

Thirty-seven dairy cows of the Icelandic breed were used in a complete change-over design experiment carried out at the Stóra-Ármót Experimental Farm in South Iceland. Three experimental treatments were assigned to two types of blocks: a) three stages of lactation; the days in milk (DIM) presented in notes under Table 1 refer to the average DIM at the start and end of a three week feeding of experimental diet within each lactation stage; b) three age groups of cows, i.e. parities: $1^{\text {st }}$ parity (1), $2^{\text {nd }}$ parity (2), $3^{\text {rd }}$ parity and older $(3+)$. The number of cows by stage of lactation and parity within each treatment are shown in Table 1. All the 37 cows in the experimental dataset finished the three treatments, in random order.

The experiment took place from January to May 2016. Each experimental period lasted five weeks. The control diet was fed during the first two weeks of each period to decrease carry-over effects. Then the experimental diet was fed for three weeks. To deal with variability of calving date within the herd, the experimental periods were four. Each cow was used in three of these four periods. The cows that calved early started 
Table 1 . Number of cows by stage of lactation and parity within each treatment. All the 37 cows finished the three treatments, in random order.

\begin{tabular}{|c|c|c|c|c|c|c|c|c|c|c|c|c|c|}
\hline \multirow{5}{*}{$\begin{array}{l}\text { Stage of } \\
\text { lactation }\end{array}$} & \multirow[b]{2}{*}{ Parity } & \multicolumn{4}{|c|}{ FAPOW } & \multicolumn{4}{|c|}{ FAPEL } & \multicolumn{4}{|c|}{ CONTROL } \\
\hline & & 1 & 2 & $3+$ & Total & 1 & 2 & $3+$ & Total & 1 & 2 & $3+$ & Total \\
\hline & 1 & 5 & 4 & 3 & 12 & 5 & 3 & 5 & 13 & 5 & 4 & 3 & 12 \\
\hline & 2 & 5 & 3 & 4 & 12 & 5 & 4 & 3 & 12 & 5 & 4 & 4 & 13 \\
\hline & 3 & 5 & 4 & 4 & 13 & 5 & 4 & 3 & 12 & 5 & 3 & 4 & 12 \\
\hline & Total & 15 & 11 & 11 & & 15 & 11 & 11 & & 15 & 11 & 11 & \\
\hline
\end{tabular}

*Stage of lactation: 1: avg. 59-80 days in milk (DIM), 2: avg. 94-115 DIM, 3: avg. 129-150 DIM

**Parity: 1: 1st parity, 2: 2nd parity, 3+: 3rd parity and older

FAPOW: a treatment with the fat supplement as powder; FAPEL: a treatment with the fat supplement in pelleted concentrate; CONTROL: control treatment without fat supplement.

in period 1 and continued throughout period 3, whereas those calving later started in period 2 and continued throughout period 4 .

\section{Treatment diets}

There were three experimental treatments:: a treatment with fat supplement in the form of a powder, Bergafat F-100 (Berg+Schmidt, Hanover, Germany), a free fatty acid product derived from palm oil (FAPOW); a treatment with the same fat supplement as a part of the pelleted feed concentrate (FAPEL); and a control treatment (CONTROL), with no fat supplement.

The forage was wilted grass silage, preserved in round bales. The silage was harvested from a primary growth of a sward with timothy as the dominant species, at the early heading stage of timothy. All three diets included high-moisture barley preserved with propionic acid. In addition, extra-fat and basic concentrates were included in the diets, as presented in Table 2.
The nutrient composition of the highmoisture barley, concentrates and fat supplement is shown in Table 3. The FA profile of the fat supplement is presented in notes under Table 3. Diets were formulated aiming at the fat supplement being $1.3-1.4 \%$ of diet dry matter (DM). The ingredient composition of the concentrates was as follows (\% of DM):

Pelleted extra - fat concentrate: wheat 10.0; maize 20.0; barley 6.5; soybean meal 31.0; sugar beet pulp 17.5; Bergafat F-100 3.5; molasses 6.0; minerals and vitamin premixes 5.5

Pelleted basic concentrate: wheat 16.0; maize 21.4; barley 11.2; soybean meal 31.0; sugar beet pulp 8.0; molasses 6.0; minerals and vitamin premixes 6.4 .

Diets were prepared as total mixed rations (TMR), mixed daily in a Mullerup ${ }^{\circledR}$ mixer. Cows were fed individually and ad lib., aiming at $10-15 \%$ feed residues. The average nutrient composition of silage and mixed rations is

Table 2. Diet ingredients (\% of DM) of experimental diets, average for all cows and all periods within each treatment. The additional concentrate serving was constant for the respective cows throughout the experiment.

\begin{tabular}{llccc}
\hline & & \multicolumn{2}{c}{ Treatment } \\
\cline { 3 - 5 } Mixed rations: & FAPOW & FAPEL & CONTROL \\
& Silage & 43.8 & 41.8 & 43.7 \\
& Barley & 10.6 & 10.1 & 10.6 \\
& Basic concentrate & 34.9 & & 34.9 \\
& Extra-fat concentrate & & 36.2 & \\
& Bergafat F-100 & 1.4 & & 10.8 \\
\hline \multirow{2}{*}{ Additional concentrate: } & & 11.9 & \\
& Basic concentrate & 9.4 & &
\end{tabular}


Table 3. Nutrient composition of high-moisture barley, feed concentrates and fat supplement.

\begin{tabular}{|c|c|c|c|c|}
\hline & Barley & $\begin{array}{l}\text { Extra-fat } \\
\text { concentrate }\end{array}$ & $\begin{array}{c}\text { Basic } \\
\text { concentrate }\end{array}$ & $\begin{array}{l}\text { Bergafat } \\
\text { F-100 a) }\end{array}$ \\
\hline Dry matter (DM), \% & 42.7 & 88.0 & 88.0 & 99.0 \\
\hline In vitro organic matter digestibility, $\%$ & 84.8 & 81.5 & 83.1 & 95.0 \\
\hline \multicolumn{5}{|l|}{ DM composition, g/kg DM } \\
\hline Ash & 43 & 100 & 109 & NA \\
\hline Neutral detergent fibre (NDF) & 163 & 153 & 153 & NA \\
\hline Crude protein $(\mathrm{CP})$ & 117 & 214 & 221 & NA \\
\hline Sugars & 87 & 78 & 75 & NA \\
\hline Starch & 467 & 249 & 324 & NA \\
\hline Short chain fatty acids & 50 & 0 & 0 & NA \\
\hline Crude fat & 21 & 55 & 22 & 1000 \\
\hline Carbohydrate rest fraction & 52 & 151 & 96 & NA \\
\hline \multicolumn{5}{|l|}{ Other measurements } \\
\hline Indigestible NDF (iNDF), g/kg DM & 27 & 17 & 20 & 0 \\
\hline Soluble crude protein $(\mathrm{sCP}), \mathrm{g} / \mathrm{kg} \mathrm{CP}$ & 474 & 201 & 206 & 0 \\
\hline
\end{tabular}

a)Fatty acid product derived from palm oil; fatty acid profile ( $\mathrm{g} / 100 \mathrm{~g}$ of total $\mathrm{FA}$ ): $\mathrm{C} 14: 0$ and shorter $\mathrm{FA} \approx 3 ; \mathrm{C}-16: 0 \geq 85 ; \mathrm{C} 18: 0 \approx 3 ; \mathrm{C}-18: 1 \approx 6 ; \mathrm{C} 18: 2 \approx 2 ; \mathrm{C}-20-0 \approx 1 ; \mathrm{NA}=$ not analysed

Table 4. Average nutrient composition of silage and mixed rations.

Dry matter (DM), \%

In vitro organic matter digestibility, $\%$

DM composition, g/kg DM

Ash

Neutral detergent fibre (NDF)

Crude protein (CP)

Sugars

Starch

Short chain fatty acids

Crude fat

Carbohydrate rest fraction

Fermentation parameters:

Ammonia $\mathrm{N}\left(\mathrm{NH}_{3}-\mathrm{N}\right), \mathrm{g} / \mathrm{kg} \mathrm{N}$

Lactic acid (LAF), g/kg DM

Acetic acid (AAF), g/kg DM

$\mathrm{pH}$

Other measurements:

Soluble crude protein (sCP), g/kg CP

Indigestible NDF (iNDF), g/kg DM

Acid detergent fibre g/kg DM

\begin{tabular}{cccc} 
Grass silage & $\begin{array}{c}\text { Mixed ration } \\
\text { FAPOW }\end{array}$ & $\begin{array}{c}\text { Mixed ration } \\
\text { FAPEL }\end{array}$ & $\begin{array}{c}\text { Mixed ration } \\
\text { CONTROL }\end{array}$ \\
33.4 & 45.4 & 44.4 & 45.8 \\
79.5 & 79.7 & 80.9 & 82.2 \\
& & & \\
81 & 78 & 78 & 78 \\
412 & 291 & 313 & 289 \\
160 & 161 & 167 & 160 \\
84 & 94 & 87 & 69 \\
0 & 187 & 152 & 183 \\
62 & 60 & 60 & 64 \\
36 & 39 & 36 & 28 \\
166 & 91 & 108 & 130 \\
& & & \\
126 & 56 & 64 & 62 \\
41 & 49 & 49 & 54 \\
16 & 11 & 11 & 11 \\
4.6 & 4.8 & 4.7 & 4.7 \\
728 & 383 & 464 & 505 \\
40 & 32 & 33 & 32 \\
241 & 192 & 197 & 193 \\
\hline
\end{tabular}


presented in Table 4. On top of the mixed rations, the highest yielding cows received an additional serving of the basic concentrate. This additional serving was determined before the start of the experiment, and kept constant for the respective cows throughout the experiment. Table 2 reports the proportional composition of the experimental diets.

\section{Data and sample collection}

The cows were housed in a tie-stall barn and milked in a SAC® milking parlour twice a day. The SAC® milking system automatically registered the milk yield of each cow at every milking, based on milk flow rate measurements with a Saccomatic IDC 3 Milk Meter, approved by ICAR (2010). Milk samples from individual cows were collected at morning and afternoon milking for the last four consecutive days of each experimental period. They were analysed for protein, fat and lactose using infrared spectrometer CombiFoss 6000 FC (Foss Electric) at the Research Centre for the Milking Industry in Iceland (Rannsóknastofa mjólkuriðnaðarins). The milk composition was used to calculate the energy-corrected milk (ECM) according to Sjaunja et al. (1990). The samples for the last day of each experimental period were combined (morning and afternoon samples) and analysed for individual FA at Matis Ltd. (Icelandic Food and Biotech R\&D). There, fat extraction was based on the method of Bligh and Dyer (1959), methylation was according to the AOCS method (AOCS, 1998), and fatty acid methyl esters (FAME) were determined by gas chromatography (Varian 3900 GC, Varian, Inc., Walnut Creek, CA) equipped with a fused silica capillary column (HP-88, $100 \mathrm{~m}$ x $0.25 \mathrm{~mm} \times$ $0.20 \mu \mathrm{m}$ film), split injector and flame ionisation detector fitted with Galaxie Chromatography Data System (Version 1.9.3.2 software, Varian Inc.).

Individual intake was registered for four consecutive days in the last week of each experimental period. The roughage and the TMR were sampled daily (four days a week), composited weekly and frozen for later analysis (24 samples of each in every treatment). A sample of residues from each treatment as well as a sample of the barley and the compound feed was collected once a week and frozen for later analysis.

The DM of the samples of roughage, TMR and feed residues was determined with a singlestep drying method by drying the samples in a hot-air drying cabinet at $60^{\circ} \mathrm{C}$ to a constant weight, for approximately $44 \mathrm{~h}$, and corrected for lost volatiles according to Porter and Murray (2001). The DM of the compound feed was determined in a hot-air drying cabinet at $103^{\circ} \mathrm{C}$ as described in European Commission Regulation EC No. 152/2009. Crude protein (CP) was calculated based on analysis of total nitrogen according to the Dumas principle (Hansen, 1989). Ash was determined at $550^{\circ} \mathrm{C}$ according to the European Commission Regulation EC No. 152/2009 and organic matter was determined by subtracting the ash from the dry matter content. In vitro organic matter digestibility (IVOS) was determined using the method presented by Tilley and Terry (1963). The neutral detergent fibre (NDF) was analysed using the Ankom technique according to the method described by Van Soest et al. (1991) except that sulphite and amylase were used for all samples (ISO 16472:2006 IDT). Starch was analysed using the polarimetric method as described in European Commission Regulation EC No. 152/2009. The water-soluble carbohydrates (WSC) in the roughage and the barley were analysed enzymatically based on the procedure of Larsson and Bengtsson (1983). Short chain fatty acids (SCFA) and ethanol in silage were analysed with the HPLC technique, adapted by Eurofins (Åkerlind et al. 2011). Soluble crude protein (sCP) and indigestible NDF (iNDF) were determined by methods reported by Åkerlind et al. (2011). The carbohydrate rest fraction was calculated as described by Volden (2011).

Cows were weighed and their body condition scores (BCS) were estimated once a week, immediately after the afternoon milking. The BCS was estimated using a scale from 1-5 with a 0.25 -unit precision. The scale used is based on the work of Wildman et al. (1982) where emaciated cows score 1 , and obese cows score 5 . 


\section{Statistical analysis}

Dry matter intake, milk production and milk composition data were summarized for each cow within each experimental period, making 111 records or experimental units (37 cows x 3 periods per cow). These records were statistically analysed by the Mixed procedure in SAS Enterprise Guide 7.1. (C) 2015, SAS Institute, Cary, NC, USA), using the following model:

$\mathrm{Y}_{\mathrm{ijk} l}=\mu+\alpha_{\mathrm{i}}+\beta_{\mathrm{j}}+\gamma_{\mathrm{k}}+(\alpha \cdot \beta)_{\mathrm{ij}}+(\beta \cdot \gamma)_{\mathrm{jk}}+\mathrm{C}_{1}+\varepsilon_{\mathrm{ijk} \mathrm{l}}$

where $\mathrm{Y}_{\mathrm{ijkl}}$ is the response variable (intake, milk production, milk composition); $\mu$ : the overall mean; $\alpha_{i}$ : the fixed effect of treatment $i ; \beta_{j}$ : the fixed effect of lactation stage $\mathrm{j} ; \gamma_{\mathrm{k}}$ : the fixed effect of parity $\mathrm{k} ;(\alpha \cdot \beta)_{\mathrm{ij}}$ and $(\beta \cdot \gamma)_{\mathrm{jk}}$ : interaction effects; $\mathrm{C}_{1}$ random effect of individual cows; $\varepsilon_{\mathrm{ijk}}$ : residual error.

The interaction effects present in the model were significant for some of the response variables. Other possible interactions were tested but as they were not significant for any of the responses, they were excluded from the statistical model.

\section{RESULTS}

No effects of treatment were found for changes in weight or body condition (data not shown). On average for the whole experiment, the cows weighed 471 (s.d. 56) $\mathrm{kg}$ and the BCS was 3.32 (s.d. 0.38).

As presented in Table 5, there were tendencies, although not significant, for the FAPEL treatment to decrease intake and increase the production of energy corrected milk. This resulted, however, in significantly higher feed efficiency for FAPEL compared to the CONTROL treatment.

As Table 5 reports, the milk protein content was significantly lower in the fat treatments compared to the CONTROL treatment. At the same time there was a tendency $(p<0.10)$ for a higher milk fat content in the fat treatments compared to the CONTROL treatment. This resulted in a significantly higher milk fat:protein ratio for both the fat treatments compared to the CONTROL treatment. There was a significant reduction in the milk casein: $\mathrm{CP}$ ratio for the fat treatments compared to the CONTROL. Furthermore, the concentration of free fatty acids (FFA) in milk was significantly higher in the fat treatments, especially FAPEL.

Table 5. The effects of treatments on dry matter intake (DMI), milk yield, milk composition, production of milk fat, milk protein and energy corrected milk; and feed efficiency estimated as production of energy corrected milk (ECM) per kg DMI. Least square treatment means and standard error of means (SEM).

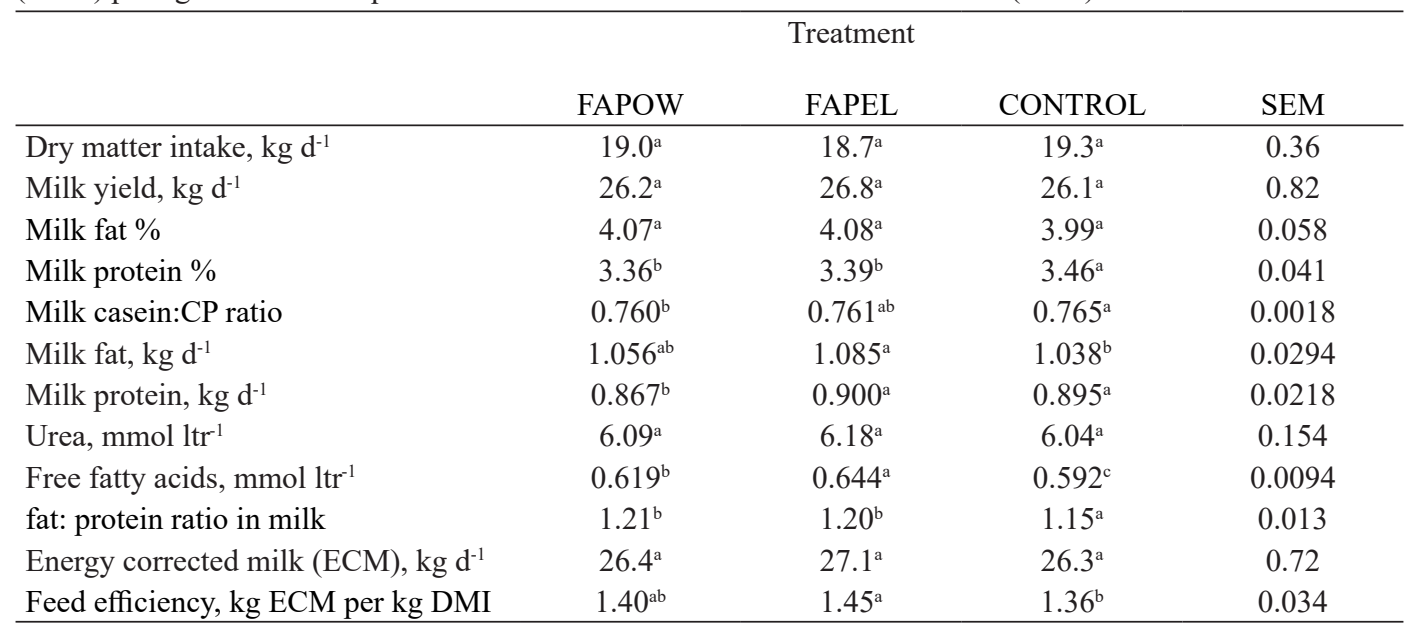


Table 6. The effects of treatments on fatty acid composition (\%) of milk fat. Least square treatment means and standard error of means (SEM).

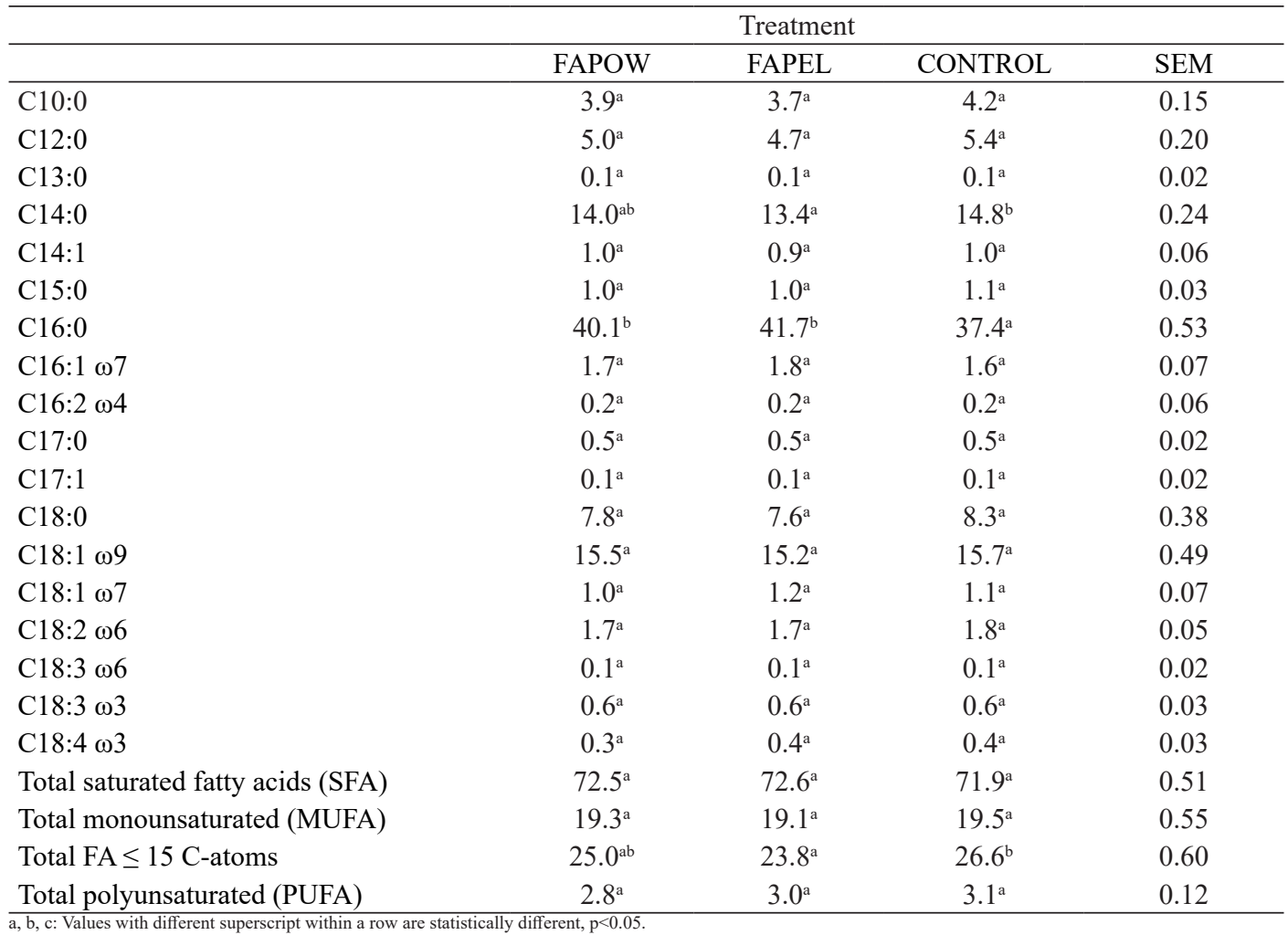

The fatty acid composition of the milk did not differ significantly between treatments (Table 6), except that the ratio of palmitic acid (C16:0) was higher in the fat treatments compared to the CONTROL, and the ratio of myristic acid (C14:0) was lowest in the FAPEL treatment.

\section{DISCUSSION}

Previous research has shown differences in production responses to fat supplements in cows at different ages, lactation stage and genetic potential (Harvatine and Allen, 2005, Weisbjerg et al., 2013). The design of the present study aimed to control these sources of variation so they would not obscure the treatment effects. We found that the fat:protein ratio in the milk was raised significantly by addition of fat to the diet. However, feeding the fat supplement as a part of a pelleted concentrate (FAPEL) was more effective with regard to total milk protein production than feeding the same fat supplement in the form of a powder (FAPOW) mixed directly into the ration.

The added fat was predominantly palmitic acid (C16:0). Milk FA that are $14 \mathrm{C}$-atoms and shorter are synthesised de novo in the mammary gland. For that purpose, ruminants utilize acetate (2 C-atoms) and butyrate (4 C-atoms) from rumen fermentation as carbon sources (Bauman and Griinari, 2003). Milk FA that are $18 \mathrm{C}$-atoms and longer are taken up from the blood circulation. In ruminants, they are predominantly derived from the intestinal absorption of dietary and microbial FA, but lipolysis and mobilization of body fat also contribute, proportionally to the energy deficit when the animal is in negative energy balance (Bauman and Griinari, 2001). FA of 16 C-atoms in length originate from both sources (Bauman and Griinari, 2003). 
Palmitic acid (C16:0) has often been reported as more effective in converting feed fat to milk fat than other FA, like stearic acid (C18:0) (Rico et al., 2014b) or FA of 14 C-atoms or shorter (Vyas et al., 2012). Furthermore, when long chain unsaturated FA like linoleic acid (C18:2) are added to ruminant diets, they are to a large extent biohydrogenated by rumen microbes to a saturated FA like stearic acid (C18:0). Therefore, adding unsaturated FA to the diet is unlikely to increase the content of long chain unsaturated FA in milk, but likely to decrease feed intake and can also be associated with production of fatty acid intermediates that induce MFD (Jenkins and McGuire, 2006).

Calcium salts of unsaturated FA have been used for decades to overcome these limitations, but with limited success. Rico et al. (2014a) tried addition of the same highpalmitic acid supplement as used in our study, compared to a control diet with no fat supplement and a diet with added calcium salt of palm FA, more than half of them being unsaturated (C18:1 and C18:2). This calcium salt fat supplement induced MFD in highproducing cows, but the high palmitic acid supplement, compared to the control diet, increased feed efficiency and milk C16 FA yield, although it did not affect total milk fat concentration or yield. The positive effects of palmitic acid addition on feed efficiency were somewhat greater than in our study (Table 5), estimated by the same ratio, ECM/DMI. Also, the effects on milk C16 FA yield were considerably greater than we found (Table 6 ). The smaller responses in our study could be explained by a considerably lower FA supplementation level; we will address that in more detail later in this discussion.

Except for these effects on palmitic acid (C16:0), the only significant effect of dietary treatments on milk content of specific FA in our study were on $\mathrm{C} 14: 0$, where the proportion was significantly lower for the FAPEL treatment compared to the CONTROL (Table 6). The content of total FA of $\leq 15 \mathrm{C}$-atoms was significantly lower in the FAPEL than the CONTROL diet. This agrees with, for example,
Lock et al. (2013), where milk FA of 4 to 14 $\mathrm{C}$-atoms all decreased in concentration when the same C16:0 enriched fat supplement as used in our study was added to the diet. In fact, a review by Grummer (1991) showed that fat supplementation usually decreases the proportion of de novo (C6:0 to $\mathrm{C} 16: 0$ ) synthesized FA in milk fat. These effects are normally more dramatic with unsaturated FA supplements. When a majority of the FA supplement is palmitic acid (C16:0) as in our and some of the above-mentioned studies, higher concentrations of C16:0 in milk can be explained by greater direct uptake of C16:0 from the circulation that accounts for more than a possible decrease in de novo C16:0 synthesis.

The level of fat supplementation in our study was relatively low compared to many studies. The FA level in the fat treatments in our study was a little less than $4 \%$ of feed DM. In the studies of Rico et al. (2014a) and Lock et al. (2013) the FA levels were, respectively, 4.8 and $5.6 \%$ in treatments with the same highpalmitic acid supplement as used in our study. Consequently, the effects on milk fat production and FA profile were in the same direction, but greater, than we found.

The choice of fat supplements for our study was based on the milk industry's requirement for a higher milk fat:protein ratio, and the findings regarding the effectiveness of palmitic acid in converting feed fat to milk fat. Our results demonstrate the potential of a moderate addition of C16:0 enriched FA supplement to increase the milk fat:protein ratio in a grass silage-based diet, where MFD is not inherent. It would be interesting to study further, under these dietary conditions, if higher levels of fat addition would have an even greater impact on the milk fat:protein ratio and result in a significantly increased ECM yield and greater positive impact on feed efficiency. It has been shown, however, that both total FA digestibility and the ratio of FA absorbed decreases with increasing intake of FA (Piantoni et al., 2013).

Larsen et al. (2012) supplemented diets of Danish Holstein and Danish Jersey cows with increasing levels of unsaturated fat from linseed 
and rapeseed. For both breeds, milk protein content decreased with increasing levels of oilseeds. Milkyield, fatandlactosewereunaffected by treatments for Danish Holsteins, but increased with raised oilseed levels for Danish Jerseys. The apparent recoveries of C18:2 n-6 and C18:3 n-3 from feed to milk decreased with increasing concentrations of these FA in feed. Nevertheless, oilseeds decreased the content of C16:0 and increased the content of unsaturated $\mathrm{C} 18 \mathrm{FA}$ in milk fat. This supported evidence from earlier research (e.g. Ekeren et al., 1992) that offering oilseeds rather than oils to ruminants provided natural protection against biohydrogenation of lipids in the rumen. Weisbjerg et al. (2013) found that while supplementation with saturated fat, predominantly palmitic acid, effectively lowered the milk protein:fat ratio, supplementation with unsaturated fat from rapeseed and linseed altered the FA composition in the same direction as the oilseeds in the cited study of Larsen et al. (2012). That kind of shift in milk FA profile is desirable with respect to effects on human health (Givens, 2010).

We found that C16:0 enriched supplements increased the total content of free FA in milk significantly and lowered the milk casein:CP ratio. The milk industry must scale these effects against the above-mentioned benefits of FA supplementation.

\section{AKNOWLEDGEMENTS}

Financial support from the Icelandic Cattle Productivity Fund and from the Dairy Industry Association (SAM) is acknowledged. We also thank the Agricultural Association of South Iceland, the owner of the Stóra-Ármót Experimental Farm, for good cooperation and support, especially Baldur I. Sveinsson for daily experimental work, and the farmers Hilda Pálmadóttir and Höskuldur Gunnarsson for various help.

\section{REFERENCES}

AOCS, 1998. Official method Ce 1b-89, In: Firestone,

D. (Ed.), Official Methods and Recommended Practices of the American Oil Chemists'society. 5th ed. American Oil Chemists' Society, Champaign, IL.
Auðhumla, 2019. www.audhumla.is. Accessed 12.03.2019, at http://www.audhumla.is/ Mjolkurposturinn/

Åkerlind M, Weisbjerg MR, Eriksson T, Togersen R, Udén P, Ólafsson BL, Harstad OM \& Volden H 2011. Feed analyses and digestion methods. In: Volden H (ed.) Norfor- the Nordic feed evaluation system. EAAP Publication No. 130. Wageningen Academic Publishers, The Netherlands, pp. 41-54.

Bauman DE \& Griinari JM 2001. Regulation and nutritional manipulation of milk fat: low-fat milk syndrome. Livestock Production Science 70, 15-29.

Bauman DE \& Griinari JM 2003. Nutritional regulation of milk fat synthesis. Annual Review of Nutrition 23, 203-227.

https://doi.org/10.1146/annurev.nutr.23.011702.073408

Beauchemin KA 2018. Invited review: Current perspectives on eating and rumination activity in dairy cows. Journal of Dairy Science 101, 47624784.

https://doi.org/10.3168/jds.2017-13706

Bligh EG \& Dyer WS 1959. A rapid method of total lipid extraction and purification. Canadian Journal of Biochemistry and Physiology 37, 911.

European Commission Regulation EC No 152/2009. Commission regulation laying down the methods of sampling and analysis for the official control of feed. Official Journal of the European Union L54/1:1-130.

Ekeren PA, Smith DR, Lunt DK \& Smith SB 1992. Ruminal biohydrogenation of fatty acids from high-oleate sunflower seeds. Journal of Animal Science 70, 2574-2580.

Grummer RR 1991. Effect of Feed on the Composition of Milk-Fat. Journal of Dairy Science 74, 3244-3257.

Givens DI 2010. Milk and meat in our diet: good or bad for health? Animal 4, 1941-1952 https://doi.org/10.1017/S1751731110001503

Guinard-Flament $\mathbf{J}$, Delamaire $\mathbf{E}$, Lemosquet S, Boutinaud M \& David Y 2006. Changes in mammary uptake and metabolic fate of glucose with once-daily milking and feed restriction in dairy cows. Reproduction Nutrition Development 46, 589-598.

https://doi.org/10.1051/rnd:2006030

Hansen B 1989. Determination of nitrogen as elementary N, as an alternative to Kjeldahl. Acta 
Agric. Scand. 39, 113-118.

Harvatine KJ \& Allen MS 2005. The effect of production level on feed intake, milk yield, and endocrine responses to two fatty acid supplements in lactating cows. Journal of Dairy Science 88, 4018-4027.

https://doi.org/10.3168/jds.S0022-0302(05)73088-5

ICAR 2010. International Committee of Animal Recording. List of approved milkmeters. Accessed at https://www.icar.org/index.php/certifications/ icar-certifications-for-milk-meters-for-cow-sheepgoats/certified-milk-meters/ [Cited 19/3-2020 ].

Jenkins TC \& McGuire MA 2006. Major advances in nutrition: Impact on milk composition Journal of Dairy Science 89, 1302-1310. https://doi.org/10.3168/jds.S0022-0302(06)72198-1

Larsen MK, Hymøller L, Brask-Pedersen DB \& Weisbjerg MR, 2012. Milk fatty acid composition and production performance of Danish Holstein and Danish Jersey cows fed different amounts of linseed and rapeseed. Journal of Dairy Science 95, 3569-3578

https://doi.org/10.3168/jds.2011-5163

Larsson K \& Bengtsson S 1983. Determination of readily available carbohydrates in plant material. Methods report no. 22. National Laboratory of Agricultural Chemistry, Uppsala, Sweden (In Swedish).

Lock AL, Preseault CL, Rico JE, DeLand KE \& Allen MS, 2013. Feeding a C16:0-enriched fat supplement increased the yield of milk fat and improved conversion of feed to milk. Journal of Dairy Science 96, 6650-6659.

https://doi.org/10.3168/jds.2013.6892

Piantoni P, Lock AL \& Allen MS 2013. Palmitic acid increased yields of milk and milk fat and nutrient digestibility across production level of lactating cows. Journal of Dairy Science 96, 7143-7154. https://doi.org/10.3168/jds.2013-6680

Porter, MG \& Murray RS 2001. The volatility of components of grass silage on oven drying and the inter-relationship between dry-matter content estimated by different analytical methods. Grass and Forage Science 56, 405-411. https://doi.org/10.1046/j.1365-2494.2001.00292.x

Rico DE, Ying Y \& Harvatine KJ 2014a. Effect of a high-palmitic acid fat supplement on milk production and apparent total-tract digestibility in high- and low-milk yield dairy cows. Journal of Dairy Science 97, 3739-3751.

https://doi.org/10.3168/jds.2013-7341

Rico JE, Allen MS \& Lock AL 2014b. Compared with stearic acid, palmitic acid increased the yield of milk fat and improved feed efficiency across production level of cows. Journal of Dairy Science 97, 1057-1066.

https://doi.org/10.3168/jds.2013-7432

Sjaunja LO, Bævre L, Junkkarainen I, Pedersen J, \& Setala J, 1990. A Nordic proposition for an energy corrected milk (ECM) formula. Paper presented at the 26th session of the International Committee for recording the productivity of Milk Animals (ICRPMA). Paris, France.

Tilley JMA \& Terry RA 1963. A two-stage technique for the in vitro digestion of forage crops. Journal of British Grassland Society 18, 104-111.

Van Soest PJ, Robertson JB \& Lewis BA 1991. Methods for dietary fiber, neutral detergent fiber, and nonstarch polysaccharides in relation to animal nutrition. Journal of Dairy Science, 74, 3583-3597.

Volden H 2011. Feed fraction characteristics. In: Volden H (ed.) Norfor- the Nordic feed evaluation system. EAAP Publication No. 130. Wageningen Academic Publishers, The Netherlands, pp. 33-40.

Vyas D, Teter BB \& Erdman RA 2012. Milk fat responses to dietary supplementation of short-and medium-chain FA in lactating dairy cows. Journal of Dairy Science 95, 5194-5202.

https://doi.org/10.3168/jds.2011-5277

Weisbjerg MR, Larsen MK, Hymøller L, Thorhauge M, Kidmose U, Nielsen JH \& Andersen JB 2013. Milk production and composition in Danish Holstein, Danish Red, and Danish Jersey cows supplemented with saturated or unsaturated fat. Livestock Science 155, 60-70.

https://doi.org/10.1016/j.livsci.2013.04.008

Wildman EE, Jones GM, Wagner PE, Boman RL, Troutt HF Jr. \& Lesch TN 1982. A dairy cow body condition scoring system and its relationship to selected production characteristics. Journal of Dairy Science 65, 495-501.

Manuscript received 15.10.2019

Accepted 24.3.2020 